\title{
Scientific production on the applicability of phenytoin in wound healing*
}

\author{
A PRODUÇÃO CIENTÍFICA ACERCA DA APLICABILIDADE DA FENITOÍNA NA \\ CICATRIZAÇÃO DE FERIDAS
}

\section{LA PRODUCCIÓN CIENTIIFICA ACERCA DE LAAPLICABILIDAD DE LA FENITOÍNA EN LA CICATRIZACIÓN DE HERIDAS}

\section{Flávia Firmino', Alessandra Maria Pereira de Almeida², Rita de Jesus Grijó e Silva², Graziela da Silva Alves² Daniel da Silva Granadeiro ${ }^{3}$, Lúcia Helena Garcia Penna ${ }^{4}$}

\begin{abstract}
Phenytoin is an anticonvulsant that has been used in wound healing. The objectives of this study were to describe how the scientific production presents the use of phenytoin as a healing agent and to discuss its applicability in wounds. A literature review and hierarchy analysis of evidence-based practices was performed. Eighteen articles were analyzed that tested the intervention in wounds such as leprosy ulcers, leg ulcers, diabetic foot ulcers, pressure ulcers, trophic ulcers, war wounds, burns, preparation of recipient graft area, radiodermatitis and post-extraction of melanocytic nevi. Systemic use of phenytoin in the treatment of fistulas and the hypothesis of topical use in the treatment of vitiligo were found. In conclusion, topical use of phenytoin is scientifically evidenced. However robust research is needed that supports a protocol for the use of phenytoin as another option of a healing agent in clinical practice.
\end{abstract}

\section{RESUMO}

A fenitoína é um anticonvulsivante que vem sendo empregado na cicatrização de ferida. Os objetivos desta pesquisa foram: descrever como a produção científica apresenta o uso da fenitoína como agente cicatrizante e discutir sua aplicabilidade em feridas. Foi realizada, para tanto, revisão integrativa da literatura e análise pela hierarquia das práticas baseadas em evidências. Assim, analisaram-se 18 artigos que testaram a intervenção em feridas como úlceras de perna, por hanseníase, pé diabético, úlceras por pressão, tróficas, ferimentos de guerra, queimaduras, preparo da área receptora de enxerto, radiodermites e pósextração de nevos melanocíticos. Uso sistêmico da fenitoína no tratamento de fístulas e a hipótese do uso tópico no tratamento do vitiligo foram achados. Conclui-se que a fenitoína tópica é uma evidência científica. No entanto necessita-se de pesquisas robustas que sustentem o uso protocolar da fenitoína como mais uma opção de agente cicatrizante na prática clínica.

\section{DESCRITORES}

Fenitoína

Cicatrização de feridas

Enfermagem baseada em evidências Revisão.

\section{RESUMEN}

La fenitoína es un anticonvulsivo que se utiliza en la cicatrización de heridas. Los objetivos de esta investigación fueron: describir cómo la producción científica presenta el uso de la fenitoína como agente cicatrizante y discutir su aplicabilidad en las heridas. Se realizó una revisión integradora de la literatura y el análisis por la jerarquía de las prácticas basadas en las evidencias. Se analizaron 18 artículos que probaron la intervención en heridas como úlceras en la pierna por hanseniasis, pie diabético, úlceras por presión, tróficas, heridas de guerra, quemadura, preparación de la zona a injertar, radiodermitis y post extracción de nevos melanocíticos. Se encontró el uso sistémico de la fenitoína en el tratamiento de fístulas y la hipótesis del uso tópico en el tratamiento del vitíligo. Se concluye que la fenitoína tópica es una evidencia científica. Sin embargo, se necesita de investigaciones sólidas que sustenten el uso protocolar de la fenitoína como una opción más, considerándolo un agente cicatrizante en la práctica clínica.

\section{DESCRIPTORES}

Fenitoína

Cicatrización de heridas

Enfermería basada en la evidencia Revisión.

\footnotetext{
* Extracted from the monograph "A produção científica acerca da aplicabilidade da fenitoína na cicatrização de feridas", Graduate Nursing Program, Rio de Janeiro State University, 2012. ${ }^{1} \mathrm{MsN}$. RN, National Cancer Institute, Rio de Janeiro, RJ, Brazil. flare_br@yahoo.com.br ${ }^{2}$ RN. Post-graduate in stomatherapy, Rio de Janeiro State University, Rio de Janeiro, RJ, Brazil. ${ }^{3}$ RN. Post-graduate in stomatherapy, Rio de Janeiro State University, Rio de Janeiro, RJ, Brazil. ${ }^{4} \mathrm{RN}, \mathrm{PhD}$. Professor at the Maternal and Child Department, Nursing School, Rio de Janeiro State University, Rio de Janeiro, RJ, Brazil.
} 


\section{INTRODUCTION}

Phenytoin is an anticonvulsant drug available in the market since 1937. It acts by blocking neuronal excitation by binding to sodium channels at rest, preventing them from becoming functional and generating excitatory action potentials ${ }^{(1)}$. The possibility of its use as a healing agent began to be investigated by primary experimental studies in the field of dentistry, when, in 1939, hypergranulation of gingival tissue was recognized as its adverse effect, which suggested possible use of this drug as a healing agent in wounds ${ }^{(2-3)}$.

The exact mechanism through which phenytoin induces tissue healing is unclear, and the ways to apply it for this purpose are not standardized ${ }^{(4)}$. However, the dissemination of satisfactory results of empirical research about the performance of phenytoin in healing chronic wounds such as pressure, vascular and diabetic ulcers, has caught the attention of nurses that deal with this theme, such as stomatherapy expert nurses.

Phenytoin is a low-cost drug, and the study of its healing capacity for clinical practice is important. However, there is a need for research that can elucidate the subject and encourage its discussion in our context. Therefore, this research chose as the subject of investigative interest the scientific production on the therapeutic potential of phenytoin in the wound healing process in humans. The objectives were to describe how the scientific production presents the use of phenytoin as a healing agent and to discuss its applicability in wounds.

\section{METHOD}

An integrative literature review from 2003 to 2011 was performed. The temporal limit is justified by the publication of the study The clinical effect of topical phenytoin on wound healing: a systematic review by the British Journal of Dermatology ${ }^{(3)}$, which, although published in 2007, adopted temporal delimitation of 1963 to the middle of the year 2003.

Inclusion criteria were: a) articles that discussed the use of phenytoin in healing any kind of tissue injury in humans, b) available in Portuguese, English or Spanish.

The integrative review was divided into six stages: the first stage was the selection of the review question, which characterizes the definition of the subject to be studied; second stage was the selection of the bibliography. The third stage was the categorization of studies considering the data collection form validated by Ursi ${ }^{(5)}$.

The fourth stage was the review of inclusion criteria, critical reading, and systematic data analysis. The fifth step was interpretation of the results, discussion, organization and tabulation of information. And the sixth step was the presentation of the review to enable the critical analysis of the findings by the reader, as recommended by the method adopted.

The guiding question of the review was: How is the healing potential of phenytoin presented in the scientific literature regarding its clinical applicability in human wounds. The selection of articles occurred in mid-April of 2012, in the following databases: Medical Literature Analysis and Retrieval System Online (MEDLINE), PubMed, Cochrane and Latin American and Caribbean Literature on Health Sciences (LILACS), accessed through the Virtual Health Library (VHL) portal. For the search of articles in the Latin American database, the descriptor phenytoin and the term wounds were used, and in the American databases, the descriptor phenytoin combined with the words wound; wound healing was used.

In MEDLINE, the descriptor phenytoin, when refined by combining it with the word wound using the boolean operator AND retrieved 92 studies. When the term wound was combined with wound healing using the Boolean operator AND, the research retrieved 82 studies. After duplicate exclusion, on a first analysis, considering titles and abstracts when available, 36 articles were selected. Repeating the same search model in PubMed and Cochrane, studies were duplicated, therefore no articles were included in this stage.

In the Latin American database, the descriptor phenytoin refined with the term wounds retrieved two studies, and one article was selected. The combination of the descriptor with the term wound healing retrieved no indication. Therefore, the preliminary selection was composed of 37 articles, which were categorized by the form adopted in this review. The categorization pointed to the need for full reading of the selected material, the texts being downloaded online and/or requested from institutional libraries. After a complete reading, 18 articles were included in the research, advancing to the fifth stage of this integrative review.

Data analysis used the level of evidence hierarchy, adopting standardized classification of evidence from one to seven: one corresponds to systematic review that examined randomized controlled trials, considered to be the type of research with highest reliability and scientific validity; Two: randomized clinical trial (RCT): with comparable groups and randomly divided in order to test interventions; Three: cohort study: study with observation and follow-up of the development of situations and/or injuries to the groups exposed to risks; Four: case-control study: interventions are applied to a given group, and the results are compared with a group which did not receive the intervention and serves as a parameter for comparison; Five: case series: the intervention is performed in several people and the outcomes analyzed and discussed in a particularized observational manner; Six: expert opinion: people considered experts opine on the possible interventions and the possible outcomes expected using 
empirical work experience, without testing the mentally prepared hypotheses; Seven: Preclinical studies - studies conducted through experimentation on live animals or in controlled situations and laboratory test tubes.

From these criteria, force of evidence can be classified as strong, moderate and weak: research levels 1 and 2 have strong research evidence, levels 3 and 4 have moderate research evidence and levels 5 and 7 have weak research evidence. Beyond the force level, evidence has a degree of recommendation generated by the following rating: $A$ - when the search result recommends the intervention, $B$ - when the search result is not conclusive, and C - when the search result contraindicates the intervention ${ }^{(6)}$. This classification was adopted in this study.

\section{RESULTS}

The analysis of 18 articles in this literature review shows evidence of topical phenytoin as a healing agent applied to a range of chronic wounds and also acute wounds, in addition to its systemic use in the management of fistulas of the gastrointestinal tract. Beneficial effects published urged the creation of the hypothesis of its topical use in the treatment of vitiligo, expanding the options for clinical investigation in other diseases that affect the skin, other than wounds themselves.

The Middle Eastern countries stand out in the scientific literature regarding the healing potential of phenytoin in humans, followed by: the United Kingdom, India, China and Brazil.

When considering the level of evidence and degree of recommendation, the United Kingdom is again highlighted, with two important strong-evidence studies published by the same author. Altogether the scientific production is typically published in English and performed in the academic medical area, especially the area of dermatological medicine, followed by endocrinology, surgery, neurology and dentistry. There was scientific production published in Portuguese, developed in the area of oncology nursing, as shown in Chart 1.

In the period of time delimitation studied in this integrative review, every year there was scientific production at an average two to three articles/year, and the year 2011 had four articles. This facet indicates an increased investigative interest on the theme in question.

Chart 1 - Studies that investigated the healing potential of phenytoin categorized by the hierarchy of scientific evidence - Rio de Janeiro 2012

\begin{tabular}{|c|c|c|c|c|c|}
\hline Title/Reference (*) & $\begin{array}{l}\text { Year/ } \\
\text { Country }\end{array}$ & $\begin{array}{c}\text { Design/ } \\
\text { Research } \mathbf{N}\end{array}$ & Interventions & Outcomes & $\begin{array}{c}\text { Evidence } \\
\text { /recomen- } \\
\text { dation }\end{array}$ \\
\hline $\begin{array}{l}\text { The clinical effect of } \\
\text { topical phenytoin on } \\
\text { wound healing: a sys- } \\
\text { tematic review }\end{array}$ & $\begin{array}{l}2007 \\
\text { United } \\
\text { Kingdom }\end{array}$ & $\begin{array}{l}\text { Systematic re- } \\
\text { view/ } 14 \text { RCT }\end{array}$ & $\begin{array}{l}\text { Unspecified topical use in sev- } \\
\text { eral types of wounds }\end{array}$ & $\begin{array}{l}\text { Moderate evidences for the use in } \\
\text { leg, leprosy, chronic, ulcers, dia- } \\
\text { betic foot. Limited evidences for } \\
\text { the use in burns and war wounds }\end{array}$ & $1 / \mathrm{A}$ \\
\hline $\begin{array}{l}\text { A systematic review of } \\
\text { randomized controlled } \\
\text { trials of treatments for } \\
\text { inherited forms of epi- } \\
\text { dermolysis bullosa }^{(7)}\end{array}$ & $\begin{array}{l}2008 \\
\text { United } \\
\text { Kingdom }\end{array}$ & $\begin{array}{l}\text { Systematic } \\
\text { review /5 RCT }\end{array}$ & $\begin{array}{l}\text { Oral pill } 5 \mathrm{mg} / \mathrm{kg} / \text { day for Epider- } \\
\text { molysis bullosa wound healing }\end{array}$ & $\begin{array}{l}\text { No significant results compared to } \\
\text { other interventions investigated }\end{array}$ & $1 / \mathrm{C}$ \\
\hline $\begin{array}{l}\text { Nonhealing wounds }-\mathrm{a} \\
\text { therapeutic dilema }^{(8)}\end{array}$ & $\begin{array}{l}2003 \\
\text { India }\end{array}$ & $\begin{array}{l}\text { RCT/N } 150 \\
\text { divided into } 3 \\
\text { groups: human } \\
\text { placenta extract, } \\
\text { phenytoin and } \\
\text { saline }\end{array}$ & $\begin{array}{l}100 \mathrm{mg} \text { pill macerated apllied } \\
\text { 1x/day in pressure, diabetic foot, } \\
\text { leprosy and venous ulcers }\end{array}$ & $\begin{array}{c}\text { Phenytoin group: healing in } 48 \% \\
\text { cases, with full healing around } \\
\text { the } 21 \text { st day in group treatment } \\
\text { and around the } 45 \text { th day in group } \\
\text { control }\end{array}$ & $2 / \mathrm{A}$ \\
\hline $\begin{array}{l}\text { The use topical phenyto- } \\
\text { in for healing of chronic } \\
\text { venous ulcerations }{ }^{(9)}\end{array}$ & $\begin{array}{l}2011 \\
\text { Egypt }\end{array}$ & $\begin{array}{l}\mathrm{RCT} / \\
\mathrm{N} 104 \\
\text { divided into } \\
\text { study group } \\
\text { (N54) and } \\
\text { control (N50) }\end{array}$ & $\begin{array}{c}\text { Manipulated lotion ( } 1 \mathrm{gr} \mathrm{de} \\
\text { phenytoin }+25 \mathrm{~mL} \text { lipossomal } \\
\text { base) applied } 1 \mathrm{x} / \text { day for } 8 \text { weeks } \\
\text { in venous ulcers }\end{array}$ & $\begin{array}{c}\text { Full healing in N35 of the study } \\
\text { group and in N26 of the control } \\
\text { group. } \downarrow \text { of ulcer surfaces was } \\
\text { higher in the study groups. } \\
\text { Burning sensation referred by N4 } \\
(7.4 \%)\end{array}$ & $2 / \mathrm{A}$ \\
\hline $\begin{array}{l}\text { Topical phenytoin } \\
\text { versus eusol in the treat- } \\
\text { ment of non- malignant } \\
\text { chronic leg ulcers }\end{array}$ & $\begin{array}{c}2003 \\
\text { Tanzania }\end{array}$ & $\begin{array}{l}\text { RCT/N } 102 \\
\text { testing two } \\
\text { interventions: } \\
\text { Phenytoin (N50) } \\
\text { x Eusol (N52) }\end{array}$ & $\begin{array}{l}\text { Macerated pills appliedto } \\
\text { traumatic, inflammation, venous, } \\
\text { diabetic, trophic ulcers, bites } \\
\text { and burns }\end{array}$ & $\begin{array}{l}\downarrow \text { pain, draining, } \\
\text { and } \uparrow \text { granulation tissue and } \\
\text { healing more significant in the } \\
\text { phenytoin group }\end{array}$ & $2 / \mathrm{A}$ \\
\hline
\end{tabular}




\begin{tabular}{|c|c|c|c|c|c|}
\hline Title/Reference $(*)$ & $\begin{array}{l}\text { Year/ } \\
\text { Country }\end{array}$ & $\begin{array}{c}\text { Design/ } \\
\text { Research N }\end{array}$ & Interventions & Outcomes & $\begin{array}{l}\text { Evidence } \\
\text { /recomen- } \\
\text { dation }\end{array}$ \\
\hline $\begin{array}{l}\text { Topical phenytoin suspen- } \\
\text { sion and normal saline in } \\
\text { the treatment of leprosy tro- } \\
\text { phic ulcers: a randomized, } \\
\text { double-blind, comparative } \\
\text { study }{ }^{(11)}\end{array}$ & $\begin{array}{l}2004 \\
\text { India }\end{array}$ & $\begin{array}{c}\text { RCT/N45 } \\
\text { comparing topi- } \\
\text { cal phenytoin } 2 \% \\
\text { and } \\
4 \%\end{array}$ & $\begin{array}{c}\text { Gauze moistened with } 100 \mathrm{mg} \\
\text { or } 200 \mathrm{mg} \text { pills dissolved in } 5 \\
\mathrm{~mL} \text { solution of saline applied in } \\
\text { leprosy ulcers } 1 \mathrm{x} / \text { day }\end{array}$ & $\begin{array}{l}\text { Effectiveness in both cases, no } \\
\text { significant difference }\end{array}$ & $2 / \mathrm{A}$ \\
\hline $\begin{array}{c}\text { Topical phenytoin solution } \\
\text { for treating pressure ulcers: } \\
\text { a prospective, randomized, } \\
\text { double-blinded clinical } \\
\text { trial }^{(12)}\end{array}$ & $\begin{array}{l}2007 \\
\text { India }\end{array}$ & $\begin{array}{c}\mathrm{RCT} / \mathrm{N} 28 \\
\text { Intervention and } \\
\text { control groups } \\
\text { (saline) with } \\
\text { assessment of } \\
\text { the systemic } \\
\text { phenytoin absor- } \\
\text { tion rate }\end{array}$ & $\begin{array}{l}\text { Gauze moistened with diluted } \\
\text { intravenous solution } 50 \mathrm{mg} / \mathrm{ml} \\
\text { in saline }(9 \mathrm{~mL}) \text { topically ap- } \\
\text { plied on pressure ulcers stage II } \\
1 \mathrm{x} / \text { day for } 15 \text { days }\end{array}$ & $\begin{array}{l}\text { Healing evaluated by PUSH } \\
\text { method evidencing slightly faster } \\
\text { healing than the control group. } \\
\text { Serum concentrations less than } \\
0.2 \mathrm{ug} / \mathrm{mL} \text { indicating negligible } \\
\text { systemic absorption }\end{array}$ & $2 / \mathrm{A}$ \\
\hline $\begin{array}{c}\text { A randomized clinical } \\
\text { trial comparing hydrocol- } \\
\text { loid, phenytoin and simple } \\
\text { dressing for the treatment of } \\
\text { pressure ulcers } \\
\text { (13) }\end{array}$ & $\begin{array}{l}2004 \\
\text { Iran }\end{array}$ & $\begin{array}{l}\text { RCT/N83 } \\
\text { paraplegic with } \\
91 \text { ulcers } \\
\text { dividided in } 3 \\
\text { groups: hydrocol- } \\
\text { loid, phenytoin } \\
\text { and saline }\end{array}$ & $\begin{array}{l}\text { Phenytoin cream applied 1x/day } \\
\text { for } 8 \text { weeks }\end{array}$ & $\begin{array}{c}\text { Hydrocolloid was more effective } \\
\text { in healing with no significant } \\
\text { differences between saline and } \\
\text { phenytoin }\end{array}$ & $2 / \mathrm{B}$ \\
\hline $\begin{array}{l}\text { A randomized clinical } \\
\text { trial comparing hydrocol- } \\
\text { loid, phenytoin and simple } \\
\text { dressing for the treatment of } \\
\text { pressure ulcers } \\
\text { (13) }\end{array}$ & $\begin{array}{l}2004 \\
\text { Iran }\end{array}$ & $\begin{array}{l}\text { RCT/N83 } \\
\text { paraplegic with } \\
91 \text { ulcers } \\
\text { dividided in } 3 \\
\text { groups: hydrocol- } \\
\text { loid, phenytoin } \\
\text { and saline }\end{array}$ & $\begin{array}{l}\text { Phenytoin cream applied 1x/day } \\
\text { for } 8 \text { weeks }\end{array}$ & $\begin{array}{c}\text { Hydrocolloid was more effective } \\
\text { in healing with no significant } \\
\text { differences between saline and } \\
\text { phenytoin }\end{array}$ & $2 / \mathrm{B}$ \\
\hline $\begin{array}{l}\text { Short report: treatment the } \\
\text { effect of topical phenytoin } \\
\text { on healing in diabetic foot } \\
\text { ulcers: a randomized con- } \\
\text { trolled trial }{ }^{(14)}\end{array}$ & $\begin{array}{l}2011 \\
\text { United } \\
\text { King- } \\
\text { dom }\end{array}$ & $\begin{array}{c}\text { RCT/N65 } \\
31 \mathrm{~N} \text { in the inter- } \\
\text { vention group } \\
\text { and } \mathrm{N} 34 \text { in the } \\
\text { control group } \\
\text { Measuring of the } \\
\text { serum level of } \\
\text { phenytoin up to } \\
16 \text { weeks }\end{array}$ & $\begin{array}{l}\text { Phenytoin alginate applied } \\
6 \mathrm{mg} / \mathrm{cm} \\
1 \mathrm{x} / \text { day }\end{array}$ & $\begin{array}{c}\text { No significant difference among } \\
\text { the groups Minimum systemic } \\
\text { absorbance }\end{array}$ & $2 / \mathrm{C}$ \\
\hline $\begin{array}{l}\text { Two percent topical phe- } \\
\text { nytoin sodium solution in } \\
\text { treating pyoderma } \\
\text { grangrenosum: a cohort } \\
\text { study }^{(15)}\end{array}$ & $\begin{array}{c}2010 \\
\text { Sri } \\
\text { Lanka }\end{array}$ & Cohort study/N6 & $\begin{array}{l}\text { Gauze moistened in a solution } \\
\text { of } 2 \% \text { phenytoin and placed on } \\
\text { resistant pyoderma gangreno- } \\
\text { sum wounds, } 1 \times \text { /day for } 4 \\
\text { weeks }\end{array}$ & $\begin{array}{l}4 \text { patients had fulls wound healing } \\
\text { and } 2 \text { had partial resolution }\end{array}$ & $3 / \mathrm{A}$ \\
\hline $\begin{array}{l}\text { Assessment of the effect } \\
\text { of phenytoin on cutaneous } \\
\text { healing from excision of } \\
\text { melanocytic nevi on the } \\
\text { face and on the back }{ }^{(16)}\end{array}$ & $\begin{array}{c}2010 \\
\text { Brazil }\end{array}$ & $\begin{array}{l}\text { Longitudinal } \\
\text { case-control/N } \\
100 \text { patients } \\
\text { with } 200 \text { lesions }\end{array}$ & $\begin{array}{c}\text { Phenytoin cream } 0.5 \% \text { applied } \\
\text { daily on injuries from removal } \\
\text { of face and neck nevi }\end{array}$ & $\begin{array}{l}\text { Lesions had more bleeding, } \\
\text { exudate and hyperemia. } \uparrow \text { edges, } \\
\text { intense epithelialization and less } \\
\text { healing time and good cosmetic } \\
\text { effects on the scar }\end{array}$ & $4 / \mathrm{A}$ \\
\hline $\begin{array}{l}\text { Wound bed preparation with } \\
10 \text { percent phenytoin oint- } \\
\text { ment increases the take of } \\
\text { swplit-hickness skin graft in } \\
\text { large diabetic ulcers }{ }^{(17)}\end{array}$ & $\begin{array}{l}2006 \\
\text { Jordâ- } \\
\text { nia }\end{array}$ & $\begin{array}{l}\text { Case-control with } \\
\text { hystological as- } \\
\text { sessment /N16 }\end{array}$ & $\begin{array}{l}\text { Phenytoin } 10 \% \text { ointment based } \\
\text { on vaseline applied } 1 \mathrm{x} / \text { day } \\
\text { in wound bed preparation of } \\
\text { diabetic foot ulcers for grafting, } \\
\text { for up to } 8 \text { weeks }\end{array}$ & $\begin{array}{l}100 \% \text { survival of the grafting in } \\
12 \\
\text { patients, } 80-90 \% \text { in } 3 \\
\text { and } 60 \% \text { in } 1 \text { patient }\end{array}$ & $4 / \mathrm{A}$ \\
\hline $\begin{array}{l}\text { The impact of topical phe- } \\
\text { nytoin on recalcitrant } \\
\text { neuropathic diabetic foot } \\
\text { ulceration }^{(18)}\end{array}$ & $\begin{array}{l}2009 \\
\text { Egypt }\end{array}$ & $\begin{array}{l}\text { Prospective case } \\
\text { series/N } 32\end{array}$ & $\begin{array}{l}\text { Aerosol phenytoin } 2 \% \text { applied } \\
\text { directly to diabetic foot wounds } \\
1 \mathrm{x} / \text { day in addition to usual } \\
\text { treatment (instrumental debride- } \\
\text { ment and cleansing with saline) } \\
\text { for } 8 \text { weeks }\end{array}$ & $\begin{array}{c}50 \% \text { patients had } \downarrow \text { of wound size } \\
\text { (mean } 18.3 \% \text { to } 38.6 \% \text { of the } \\
\text { wound area) }\end{array}$ & $5 / \mathrm{A}$ \\
\hline
\end{tabular}




\begin{tabular}{|c|c|c|c|c|c|}
\hline Title/Reference (*) & $\begin{array}{l}\text { Year/ } \\
\text { Country }\end{array}$ & $\begin{array}{c}\text { Design/ } \\
\text { Research N }\end{array}$ & Interventions & Outcomes & $\begin{array}{c}\text { Evidence } \\
\text { /recomen- } \\
\text { dation }\end{array}$ \\
\hline $\begin{array}{l}\text { Phenytoin-induced lym- } \\
\text { phocytic chemotaxis, an- } \\
\text { giogenesis and accelerated } \\
\text { healing of decubitus ulcer in } \\
\text { a patient with stroke }{ }^{(19)}\end{array}$ & $\begin{array}{c}2004 \\
\text { Greece }\end{array}$ & $\begin{array}{c}\text { Comparative } \\
\text { case study with } \\
\text { biopsy analysis } \\
\text { of } 2 \text { wounds in } 1 \\
\text { patient }\end{array}$ & $\begin{array}{c}5 \mathrm{~mL} \text { IV phenytoin }(250 \mathrm{mg}) \\
\text { apllied on a pressure ulcer in } \\
\text { sacral region in a paraplegic } \\
\text { patient } 1 \mathrm{x} / \text { day for } 2 \text { weeks as- } \\
\text { sociated with standard treatment } \\
\text { (debridement, antiseptic and dry } \\
\text { gauze) }\end{array}$ & $\begin{array}{l}\text { Faster healing by stimulating } \\
\text { lymphocyte chemotaxis and super } \\
\text { regulation of angiogenesis only } \\
\text { in lesions treated with topical } \\
\text { phenytoin }\end{array}$ & $5 / \mathrm{A}$ \\
\hline $\begin{array}{l}\text { Therapeutic potential of } \\
\text { phenyotin in radiodermitis } \\
\text { healing }{ }^{(4)}\end{array}$ & $\begin{array}{l}2007 \\
\text { Brazil }\end{array}$ & Case report/N1 & $\begin{array}{l}1 \mathrm{~mL} \text { phenyotin }(50 \mathrm{mg}) \text { dilluted } \\
\text { in } 5 \mathrm{ml} \text { saline applied } 2 \mathrm{x} / \text { day in } \\
\text { radiodermitis wound stage III } \\
\text { with } 5 \times 3 \mathrm{~cm} \text { in cervical region } \\
\text { for } 13 \text { days }\end{array}$ & $\begin{array}{l}\text { Complete epithelialization which } \\
\text { enabled cervical motion before } \\
\text { impossible }\end{array}$ & $5 / \mathrm{A}$ \\
\hline $\begin{array}{c}\text { Does phenytoin improve } \\
\text { the healing of gastintestinal } \\
\text { fistulas? }\end{array}$ & $\begin{array}{l}2011 \\
\text { Saudi } \\
\text { Arabia }\end{array}$ & Case report/N2 & $\begin{array}{c}300 \mathrm{mg} / \text { day pills for } 10 \text { days via } \\
\text { nasogastric tube in patients with } \\
\text { pancreatic and colon-cutaneous } \\
\text { fistula }\end{array}$ & $\begin{array}{l}\text { Significant decrease of the effluent } \\
\text { amount from the } 4 \text { th day of use }\end{array}$ & $5 / B$ \\
\hline $\begin{array}{l}\text { Topical phenytoin } \\
\text { treatment in bimaxillary } \\
\text { osteomyelitis secondary } \\
\text { to infantile osteopetrosis: } \\
\text { report of a case }{ }^{(21)}\end{array}$ & $\begin{array}{l}2006 \\
\text { Turkey }\end{array}$ & Case study/N1 & $\begin{array}{c}\text { Macerated } \\
\text { pill apllied in a thin layer of } \\
20 \mathrm{mg} / \mathrm{cm} 2 \text { and steryle gauze } 1 \mathrm{x} / \\
\text { day for } \\
2 \text { weeks in bone exposition in } \\
\text { oral cavity for osteomyelitis }\end{array}$ & $\begin{array}{c}\text { Granulation and covering of bone } \\
\text { exposure in } 10 \text { days }\end{array}$ & 5/A \\
\hline $\begin{array}{l}\text { Phenytoin as a novel anti- } \\
\text { vitiligo weapon }^{(22)}\end{array}$ & $\begin{array}{c}2005 \\
\text { Iran }\end{array}$ & $\begin{array}{l}\text { Expert opinion / } \\
\text { hypothesis }\end{array}$ & $\begin{array}{l}\text { Unspecified topic formula used } \\
\text { in vitiligo lesions }\end{array}$ & $\begin{array}{l}\text { Phenytoin would act by stimu- } \\
\text { lating melanocytes. Animal } \\
\text { experiments are suggested to test } \\
\text { the hypothesis }\end{array}$ & $6 / \mathrm{A}$ \\
\hline
\end{tabular}

The scientific production analyzed is characterized by the investigation of the healing potential of phenytoin by applying macerated pills directly on the wound, or the solution obtained from macerated pills or intravenous solution, both diluted in saline at a concentration of 5 or 10 $\mathrm{mg} / \mathrm{mL}$ as shown in Table 1 . Cream, ointment, alginate, lotion and aerosol were also other methods of application presented in the scientific production analyzed, although less frequently.

The clinical applicability of phenytoin for the purpose of healing wounds occurred primarily in diabetic foot and venous ulcers, followed by pressure and leprosy ulcers. The other lesions were: osteomyelitis in the oral cavity, pyoderma gangrenosum, radiodermitis grade III, and those resulting from excision of melanocytic nevi.

Overall, the studies were incomplete when describing how the phenytoin application was applied in the RCT, and the quality of methodological designs is still predominantly low, as was indicated in the pioneering work of Shaw and colleagues ${ }^{(3)}$.

\section{DISCUSSION}

Benefits from the use of phenytoin were associated with increased granulation tissue, angiogenesis, and decreasing of wound size. In cases when the drug was used systemically for the management of fistulas, there was a significant decrease of the effluent flow - which suggests a likely decline in the size of the fistulas that can be justified by the anatomic healing process, probably induced by phenytoin ${ }^{(20)}$.

Although the mechanisms by which phenytoin heals human tissues are unclear, in vitro studies in laboratory animals and in human histopathology have contributed some information to the understanding of this phenomenon, by demonstrating stimulatory action of the drug on fibroblasts and collagen synthesis, cellular remodeling, inhibition of collagenase, and acceleration of autocrine and paracrine activity of growth factors through biochemical regulation of cell receptors involved ${ }^{(3-4,8)}$ and significant lymphocyte activation ${ }^{(20)}$. 
It is noteworthy that studies of moderate to strong evidence pointed to the analgesic effects of this drug for wounds ${ }^{(10)}$, and their authors mentioned the use of phenytoin as a secure application ${ }^{(10,12,15)}$, important factors when one is concerned about systemic absorption that application of topical phenytoin may trigger.

In terms of comparisons, it is emphasized that topical phenytoin showed healing potential higher than saline, although lower than hydrocolloid ${ }^{(13)}$. This fact makes the use of phenytoin as a healing agent attractive to health services devoid of greater resources for the acquisition of high-tech curative materials.

The scientific production on the healing potential of phenytoin is characterized by research on wounds that are classic problems for generating costs to the public system of global health, exacerbated in developing countries. Again it is important to consider that this drug was considered safe, inexpensive and effective in wound healing by several researchers considered in this integrative review ${ }^{(4,8-12,16-17,19,21)}$.

However, further research should be performed to fill in knowledge gaps on the topic. One example is that, notoriously, the same author who published a level-1 evidence study with inconclusive results regarding the application of the product on wounds, could not support the use of phenytoin as a healing product in diabetic foot ulcers when doing an experiment with evidence level 2 using alginate formulation, unprecedented in the scientific literature on the subject. However, the author did not discuss this preference $\mathrm{e}^{(14)}$.

Surprisingly, phenytoin has been systemically used for the purpose of healing fistulas of the gastrointestinal tract, with encouraging results, although supported by weak research evidence and therefore with low strength of recommendation $^{(20)}$. However, it is a piece of information of interest to the field of oncology, including the use of phenytoin in healing radiodermitis grade $\mathrm{III}^{(4)}$. Another study, not included in this review because it was not available at the time of the search in the indexed databases, investigated the use of phenytoin $0.5 \%$ for mouthwash in patients suffering from oral mucositis, resulting in improved quality of life of the group that received intervention ${ }^{(23)}$.

The use of topical phenytoin in the form of $100 \mathrm{mg}$ macerated pills diluted with $5 \mathrm{~mL}$ of $0.9 \%$ saline solution, applied $12 / 12 \mathrm{hr}$ on a stage-4 pressure ulcer in the sacral region on a 50-year-old patient confined to bed for multiple sclerosis sequelae, was performed by Brazilian physicians and medical students in the northern region of the country. They reported that in 72 days the ulcer was completely filled with granulation tissue ${ }^{(24)}$. This was a study approved by the Research Ethics Committee with evidence level 5, with degree of recommendation $5 \mathrm{~A}$. But this study was also not included in this review because it was not available in the indexed databases.
In the Middle East, spray phenytoin is available for wound healing, a product known as Healosol Spray: Wound Healing Promoter. Produced by the pharmacological company ACODIMA (Arab Company for Drug Industries Medical Appliances), it has as one of its indications the use in burn wounds ${ }^{(25)}$, which again refers to the applicability of phenytoin in radiodermatitis burns, like studies number 4 and 11 of this review.

In Jordan in 2012, a preclinical study conducted on laboratory animals was published investigating the potential for wound healing of ethosuximide, barbituric acid and phenobarbital due to their structural similarity with phenytoin. The authors concluded that ethosuximide has clinical potential for the treatment of chronic wounds like phenytoin ${ }^{(26)}$, making new hypotheses emerge from clinical research in the field of healing of tissue injuries. It can be inferred that researchers have begun to investigate the healing potential of drugs similar to phenytoin.

The formulation of phenytoin solution from pills, capsules or intravenous use is inconvenient for topical use because of low solubility and high pH (around 12), which may have stinging and burning sensations as adverse effects ${ }^{(4,21)}$. Hence the importance of the use of more specific formulations. In this sense, the Pharmacy School of the Royal College of Surgeons in Ireland - RCSI - has researched formulations that may provide greater solubility of phenytoin with a $\mathrm{pH}$ around 7-8 to be administered to wounds ${ }^{(27)}$.

The global organization of pharmacovigilance - the US Food and Drug Administration - known by the acronym FDA, has approved the use of originally systemic products for the topical treatment of wounds, including anesthetics, antibiotics, and growth factors. In order to describe such situations in which a product is used for other purposes than those indicated in the package insert, the term off-label prescription medication ${ }^{(28)}$ was created.

Misoprostol, lidocaine, nifedipine, gentamicin and metronidazole are examples of drugs being prescribed to treat wounds in cream formulations, macerated pills, gel and spray, using the concept that can be called, in Brazil, off-label prescribing ${ }^{(28-29)}$. It is a controversial practice, although it exists in our environment, such as the use of substances based on essential fatty acids (EFA) widely used as healing wounds, but still lacking quality studies to support use regarding safety and efficacy issues(30). The FDA accepts clinical studies that support the safety and efficacy of the applicability of the drugs in off-label uses, as well as the National Health Surveillance Agency - ANVISA - the regulatory agency in Brazil, which opens promising fields for research.

\section{CONCLUSION}

The integrative literature review performed in this study concluded that topical phenytoin has strong evidence 
of beneficial effects on the healing process in venous, pressure, diabetic foot, leprosy, pyoderma gangrenosum ulcers and bed preparation for grafting. However, the studies conducted have moderate to low quality. More robust studies which support the use of phenytoin protocol as another option of healing agent in clinical practice are necessary.

\section{REFERENCES}

1. Hasamnis AA, Mohanty BK, Patil S. Evaluation of wound healing effect of topical phenytoin on excisional wound in albino rats. J Young Pharm. 2010;2(1):59-62.

2. Arya R, Gulati S. Phenytoin-induced gingival overgrowth. Acta Neurol Scand. 2012; 125(3):149-55.

3. Shaw J, Hughes CM, Lagan KM, Bell PM. The clinical effect of topical phenytoin on wound healing: a systematic review. $\mathrm{Br}$ J Dermatol. 2007;157(5):997-1004.

4. Firmino F. Potencial terapêutico da fenitoína na cicatrização de radiodermites. Esc Anna Nery Rev Enferm. 2007;11(1):143-9.

5. Souza MT, Silva MD, Carvalho R. Revisão integrativa: o que é e como fazer. Einstein. 2010;8(1 Pt 1):102-6.

6. Soares BGO. Prática de enfermagem baseada em vidências. In: Bork AMT. Enfermagem baseada em evidências. Rio de Janeiro: Guanabara Koogan; 2005. p. 3-13.

7. Langan SM, Williams HC. A systematic review of randomized controlled trials of treatments for inherited forms of epidermolysis bullosa. Clin Exp Dermatol. 2008; 34(1):20-5.

8. Chauhan MBBS, Rasheed A, Pandley SS, Shukla MS. Nonhealing wounds: a therapeutic dilemma. Int J Low Extrem Wounds. $2003 ; 2(1): 40-5$.

9. Hokkam E, El-Labban G, Shams M, Rifaat S, El-Mezaien M. The use of topical phenytoin for healing of chronic venous ulcerations. Int J Surg. 2011;9(4):335-8.

10. Carneiro PM, Nyawawa ET. Topical phenytoin versus eusol in the treatment of non-malignang chronic leg ulcers. East Afr Med J. 2003;80(3):124-9.

11. Bhatia A, Nanda S, Gupta U, Gupta S, Reddy BSN. Topical phenytoin suspension and normal saline in the treatment of leprosy trophic ulcers: a randomized, double-blind, comparative study. J Dermatolog Treat. 2004;15(5):321-7.

12. Subbanna PK, Shanti MFX, George J, Tharion G, Neelakantan $\mathrm{N}$, Durai S, et al. Topical phenytoin solution for treating pressure ulcers: a prospective, randomized, double-blind clinical trial. Spinal Cord. 2007;45(11):739-43.

13. Hollisaz MT, Khedmat $H$, Yari F. A randomized clinical trial comparing hydrocolloid, phenytoin and simple dressings for the treatment of pressure ulcers [ISRCTN33429693]. BMC Dermatol. 2004;4(1):18.
Considering the way as scientific production presented the healing potential of phenytoin, the importance of incentives to produce studies that show its potential indications in the healing process are needed, which will greatly contribute to the revision and updating of care measures developed by nursing and other areas of healthcare, technology and innovation.

14. Shaw J, Hughes $M$, Lagan $K M$, Stevensont $M R$, Irwin $C R$, Bell PM. The effect of topical phenytoin on healing in diabetic foot ulcers: a randomized controlled trial. Diabet Med. 2011;28(10):1154-7.

15. Fonseka HFS, Ekanayake SMB, Dissanayake M. Two percent topical sodium solution in treating pyoderma gangrenosum: a cohort study. Int Wound J. 2010;7(6):519-23.

16. Pereira CAZ, Alchorne AO. Assessment of the effect of phenytoin on cutaneous healing from excision of melanocytic nevi on the face and on the back. BMC Dermatol. 2010;10:7.

17. Younes N, Albsoul A, Badran D, Obedi S. Wound bed preparation with 10 percent phenytoin ointment increases the take of split-thickness graft inlarge diabetic ulcers. Dermatol Online J. 2006;12(6):5.

18. El-Nahas M, Gawish H, Tarshoby M, State O. The impact of topical phenytoin on recalcitrant neuropathic diabetic foot ulceration. J Wound Care. 2009;18(1):33-7.

19. Pitiakoudis M, Giatromanolak A, Iliopoulos L, Tsaroucha AK, Simopoulos C, Piperidou C. Phenytoin-induced lymphocytic chemotaxis, angiogenesis and accelerated healing of decubitus ulcer in a patient with stroke. J Int Med Res. 2004;32(2):201-5.

20. Jaber S, Rihy Z, Joseph R, Al-Khayat M. Does phenytoin improve the healing of gastrointestinal fistulas? Case Rep Gastroenteral. 2011;5(1)52-5.

21. Er N, Kasaboglu O, Atabek A, Oktemer K, Akkocaoglu M. Topical phenytoin treatment in binaxillary osteomyelitis secondary to infantile osteopetrosis: report of a case. J Oral Maxillofac Surg. 2006;64(7):1160-4.

22. Namazi MR. Phenytoin as a novel anti-vitiligo weapon. J Atoimmune Dis. 2005;2:11.

23. Baharvand M, Sarrafi M, Alavi K, Jalali Moghaddam E. Efficacy of topical phenytoin on chemotherapy-induced oral mucositis; a pilot study. Daru. 2010;18(1):46-50.

24. Santos Junior EP, Batista RRAM, Oliveira RB, Bezerra NMF, D’Albuquerque e Castro LF. O uso de fenitoína na cicatrização de úlcera por pressão: desafio terapêutico. Rev Cient ITPAC [Internet]. 2011;4(2):4-9. [2012 maio 7). Disponível em: http://www.itpac.br/hotsite/revista/artigos/42/7.pdf
Scientific production on the applicability of phenytoin in wound healing Firmino F, Almeida AMP, Silva RJG, Alves GS, Granadeiro DS, Penna LHG 
25. ACDIMA International. Medical aerosols [Internet]. 2012 [cited 2012 May 07]. Available from: http://www.acdimatrading.com

26. Ajwee DM, Disi AM, Qunaibi EA, Taha MO. Ethosuximide and Phenobarbital Promote Wound Healing via Enhancing Collagenization. Chem Biol Drug Des. 2012; 79(1):137-42.

27. Kelly JG. Technology Transfer Manager. Royal College of Surgeons in Ireland. RCSI. Topgel. Irlanda patent PCT/ EP 2005/008344. 2005. Available from: http://www.docstoc. com/docs/47619418/A-New-Product-for-the-Treatment-ofChronic-Wounds

28. Smith RG. Off-label use of prescription medication: a literature review. Wounds. 2010;22(4):78-86.
29. Brasil. Ministério da Saúde; Secretaria de Ciência, Tecnologia e Insumos Estratégicos, Comissão Nacional de Incorporação de Tecnologias no SUS. Uso off label: erro ou necessidade? Rev Saúde Pública [Internet]. 2012 [citado 2013 jun. 06];46(2):398-9. Disponível em: http://www.scielo.br/pdf/ rsp/v46n2/it_decit.pdf

30. Ferreira AM, Souza BMV, Rigotti MA, Loureiro MRD. The use of fatty acids in wound care: an integrative review of the Brazilian literature. Rev Esc Enferm USP [Internet]. 2012 [cited 2013 June 06];46(3):752-60. Available from: http:// www.scielo.br/pdf/reeusp/v46n3/en_30.pdf 